\title{
Tanzanian mushrooms and their uses 5. Some notes on the Gasteromycetes
}

\author{
FRANCISCO D. CALONGE, MARJA HÄRKÖNEN, TINA SAARIMÄKI and LEONARD \\ MWASUMBI
}

\begin{abstract}
CALONGE, F.D., HÄRKÖNEN, M., SAARIMÄKI, T. \& MWASUMBI, L. 1997: Tanzanian mushrooms and their uses 5. Some notes on the Gasteromycetes. Karstenia 37:3-10.Helsinki. ISSN 0453-3402

Ten species of Gasteromycetes (Basidiomycotina) collected in Tanzania are described or mentioned in this article. Phallus tenuis (E. Fisch.) Kuntze seems to represent the first record for Africa.

Key words: Africa, Gasteromycetes, mycology, Tanzania, taxonomy

Francisco D. Calonge, Real Jardín Botánico, CSIC, Plaza de Murillo, 2, E-28014 Madrid, Spain

Marja Härkönen and Tiina Saarimäki, Department of Ecology and Systematics, P.O. Box 7, FIN-00014 University of Helsinki, Finland

Leonard Mwasumbi, Department of Botany, University of Dar es Salaam, P.O. Box 35060, Dar es Salaam, Tanzania
\end{abstract}

\section{Introduction}

Within the framework of the research project on Tanzanian mushrooms (see Härkönen 1992, Härkönen et al. 1993a,b,c, 1994a,b, 1995 and Saarimäki et al. 1994) Härkönen, Saarimäki and Mwasumbi have carried out intensive forays to collect wild mushrooms in Tanzania. Among the collected fungi there are ten species of Gasteromycetes, which were sent for identification to Madrid, to our first author, Calonge, who is a specialist in this group of fungi. The material is preserved at the herbaria of the Botanical Museum of the University of Helsinki $(\mathrm{H})$ and Real Jardín Botánico of Madrid (MA-Fungi).

\section{Cyathus montagnei Tul.}

Monograph. Nidulariées, in Ann. Sc. Natur. sér. 3, 1:70. 1844

Basidioma cyathiform, 5-8 $\mathrm{mm}$ in height and 4 $5 \mathrm{~mm}$ in diam, on the top, sulcate, smooth inside and hirsute-strigose outside. Hairs cinnamon reddish disappearing partially from the upper part. Peridioles lenticular, $1-2 \mathrm{~mm}$ in diam, greyish brilliant with funiculus and tunica. Spores oval to elliptical, $16-18 \times 9-11 \mu \mathrm{m}$, with walls $2-3 \mu \mathrm{m}$ thick.

Cyathus montagnei is close to $C$. striatus Pers., which has different coloured peridioles, hairs of outer surface being greyish and the inner surface only slightly striate (Bottomley 1948). Regarding spore dimensions, we find notorious differences among authors. Thus, they are $20 \times$ $12 \mu \mathrm{m}$ for Brodie (1975), $20 \times 13.2 \mu \mathrm{m}$ for Saccardo (1888), 7.5-14.4 × 5.2-7.2 $\mu \mathrm{m}$ for Bottomley (1948). Cyathus montagnei has been reported from South Africa (Bottomley 1948), Central Africa (Dissing \& Lange 1962), South and Central America, West Indies, Philippines, Thailand, and Sri Lanka (Wolf 1949, Brodie 1975). 


\section{Specimens examined}

Tanzania. Tanga Prov.: Lushoto Distr., W Usambara Mts, Mazumbai, on the outskirts of the village, on wood, 1400-1500 m, 18.IV.1991 Saarimäki \& al. 910.

\section{Cyathus rudis Pat.}

Champ. de Madagascar, Mém. Acad.

Malagache, fasc. 6:35. 1927 — Fig. 1

Basidioma obconical, 5-6 $\mathrm{mm}$ in height and 3-5 $\mathrm{mm}$ in diam, on the top. Inner surface striate, greyish, glabrous. Outer surface hirsute with reddish hairs. Peridioles lenticular, $1-2 \mathrm{~mm}$ in diam, greyish, with funiculus and tunica. Spores oval to elliptical, $8-10 \times 4-5 \mu \mathrm{m}$, with walls 1 $\mu \mathrm{m}$ thick.

Cyathus rudis is close to C. chevalieri Hariot \& Pat., which has larger basidiomata, up to $20 \mathrm{~mm}$ height, and shorter spores, $8 \times 5 \mu \mathrm{m}$. Patouillard's description gives spores $9-12 \times 5 \mu \mathrm{m}$ (Brodie 1975). C. rudis is also related to C. novae-zeelandiae Tul., but the latter has smaller peridioles and spores (Brodie 1975). C. rudis has been reported from Madagascar, New Caledonia and Amboina (Brodie 1975).

\section{Specimens examined}

Tanzania. Eastern Prov.: Morogoro Distr., Kimboza Forest Reserve, caespitose on rich soil, $440 \mathrm{~m}$, 31.III.1991 Saarimäki \& al. 788.

Geastrum corollinum (Batsch) Hollós Magy. Gast.: 57-58. 1903 - Fig.2

Geastrum recolligens (With.) Desvaux, J. Bot. Paris 2:102. 1809 1826

Geastrum mammosum Chevalier, Fl. Paris 1:359.

Basidioma saccate, $15 \mathrm{~mm}$ in height before ripeness, then opens, as much as $30 \mathrm{~mm}$ in diam, strongly hygroscopic. Endoperidium sessile with fibrillose peristome distinctly delimited. Spores 3-4 $\mu \mathrm{m}$ in diam, including ornamentation, with warts $0.5 \mu \mathrm{m}$ long. Capillitium 1-6 $\mu \mathrm{m}$ in diam.

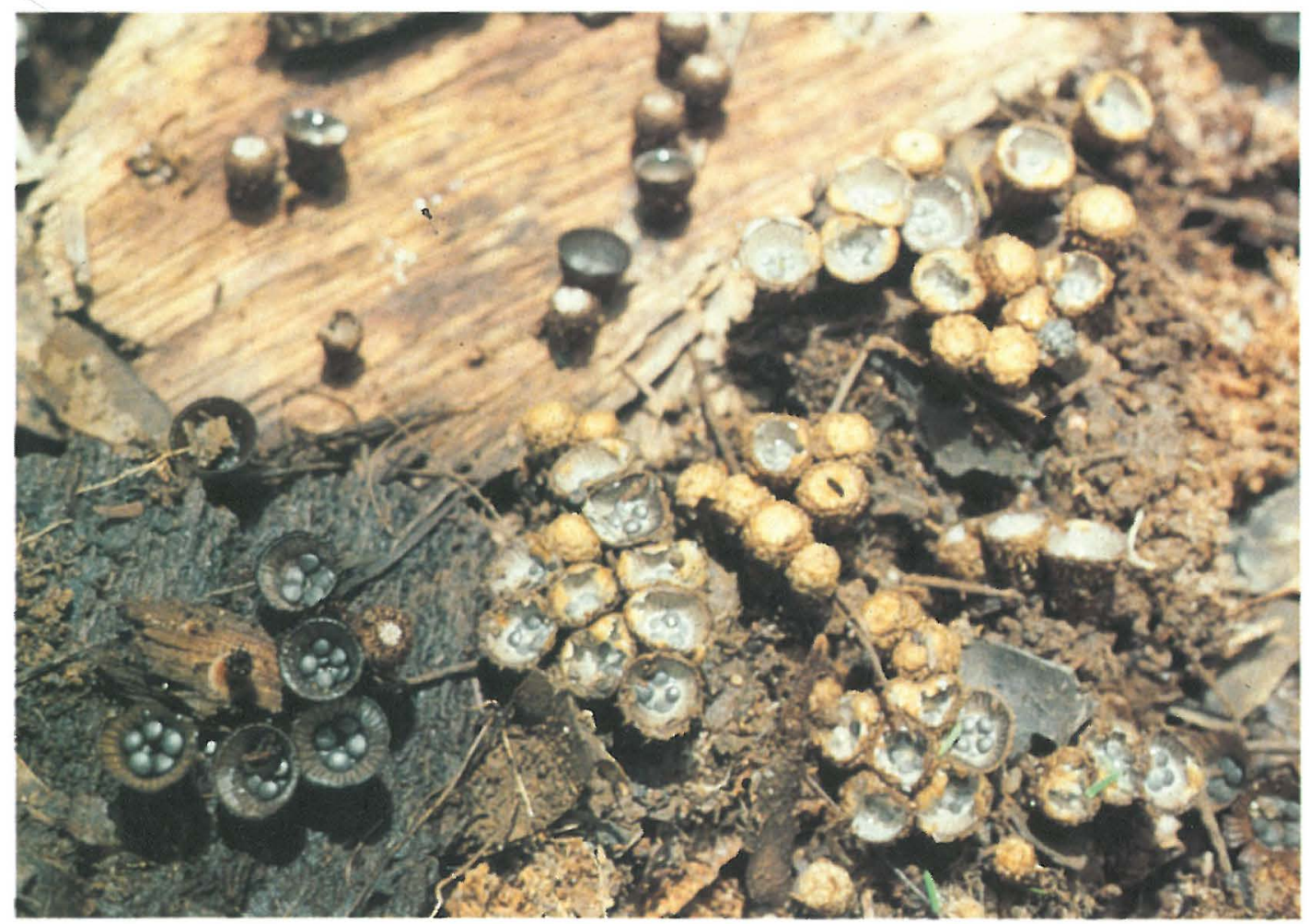

Fig. 1. Cyathus rudis. 


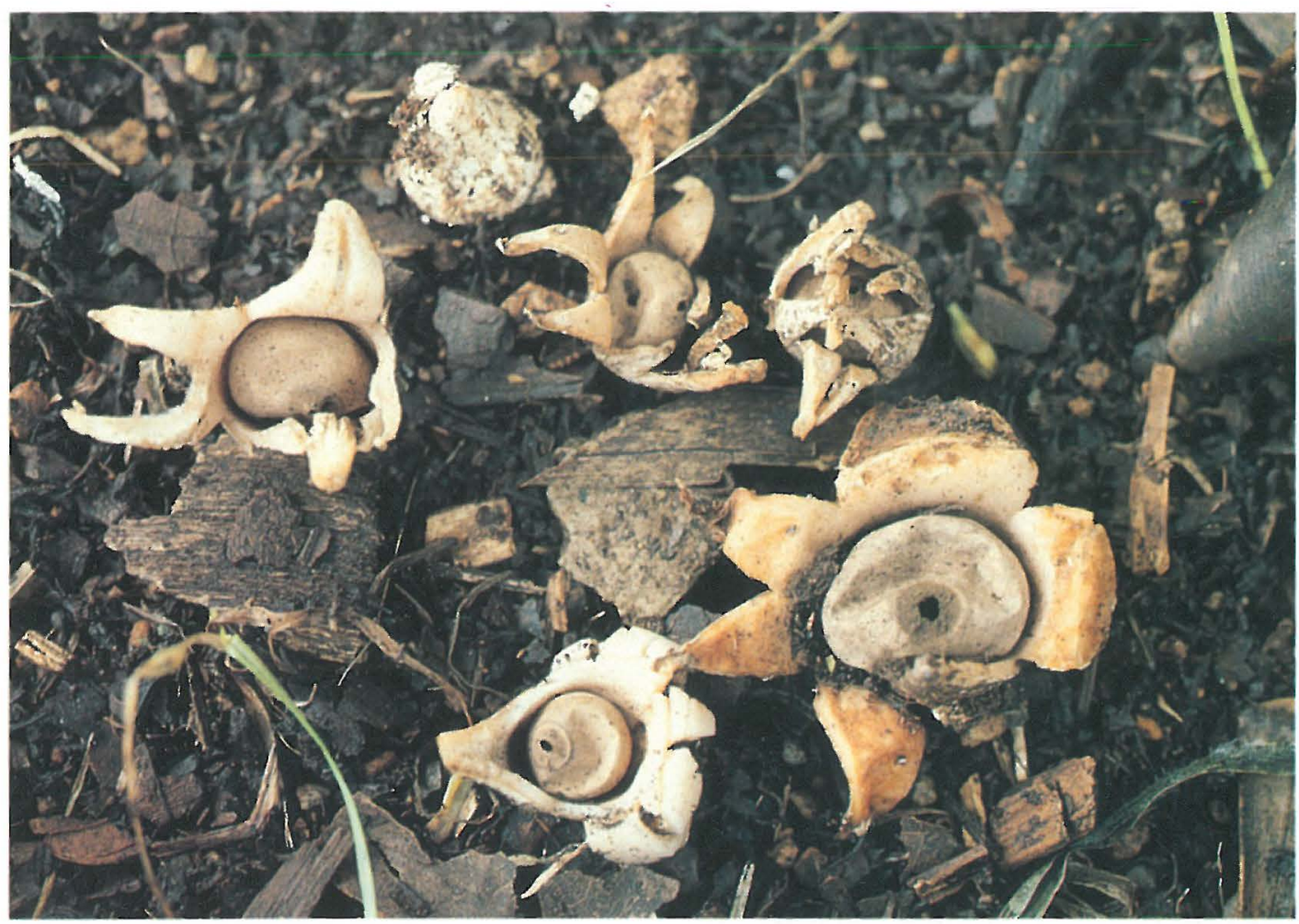

Fig. 2. Geastrum corollinum.

The specimen is very similar to the European material (Sunhede 1989, Calonge 1990), but in this case spores are slightly larger, 4-5.5 $\mu \mathrm{m}$ in diam. This species has also been reported from Asia (Eckblad 1976, Kreisel 1975, 1976), South Africa and North America (Staněk 1958).

Specimens examined

Tanzania. Southern Highlands Prov.: Rungwe Distr., Mwakaleli, Old Missionary House, on soil under a tree, 1650 m, 27.III.1991 Saarimäki \& al. 729.

\section{Geastrum drummondii Berk.}

Hooker's Lond. J. Bot. 4:63. 1845 - Figs. 3-4

Basidioma hygroscopic, with exoperidium splitting into 7-10 subequal rays, which are expanded when wet, reaching $15 \mathrm{~mm}$ diam. Fleshy layer

Figs. 3-4. Geastrum drummondii. Spores with warts flattened or truncate, sometimes joined into conical structures.
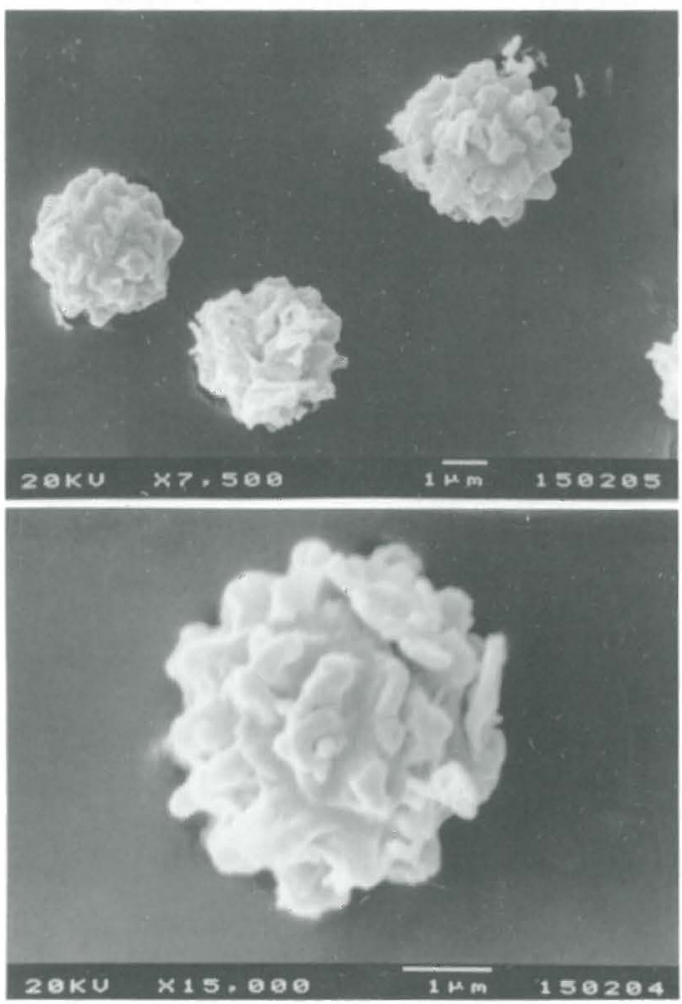
chocolate brown in exsiccata. Fibrous layer whitish. Mycelial layer thin, membranous, covered with debris, easily detached. Endoperidium globose, 7-10 $\mathrm{mm}$ in diam, sessile, whitish to greyish brown. Peristome sulcate, distinct or indistinctly delimited. Spores globose, 4-5 $\mu \mathrm{m}$ in diam, including flattened warts (Figs. 3-4). Capillitium solid, 1-5 $\mu \mathrm{m}$ thick, without septa or branches.

Our specimen fits well the description of this taxon given by Dissing \& Lange (1962) and Dring (1964) for material collected in tropical West Africa. However, the type material has slightly larger spores (5.5-7.5 $\mu \mathrm{m}$ in diam) according to Sunhede (1989:121). Geastrum drummondii has also been reported from Australia and Tasmania (Dring 1964). Regarding the possible affinities of $G$. drummondii, Sunhede (1989:120-121) considers that it could well be
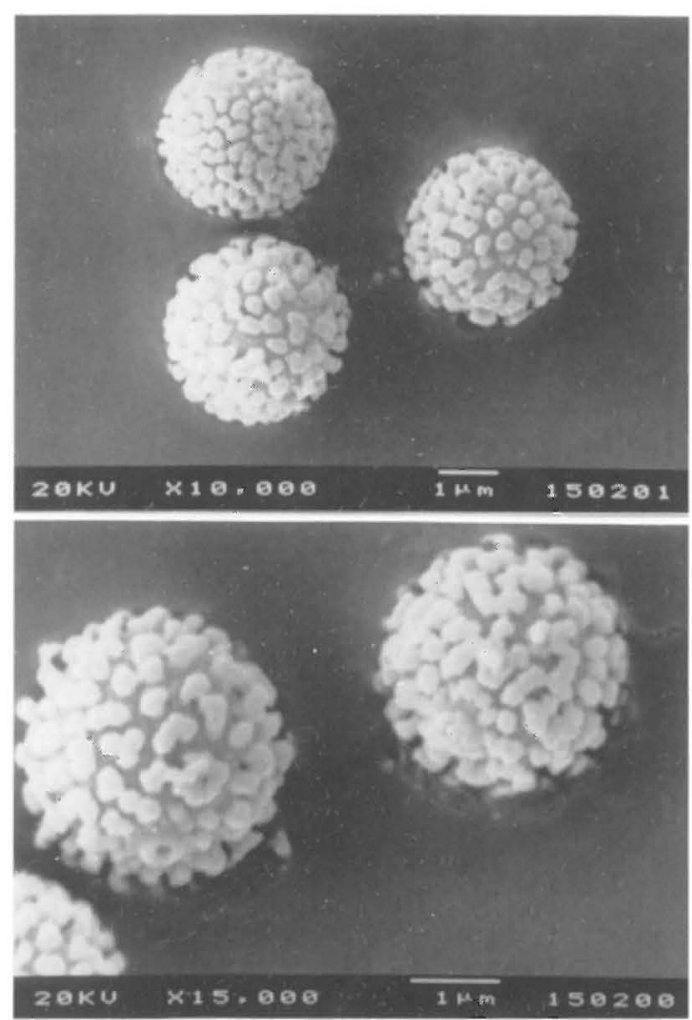

Figs. 5-6. Geastrum hariotii. Spores with flattened hemispherical warts, normally isolated, showing a uniform distribution. identical with G. ambiguum Mont., and $G$. campestre Morgan. And if this is so, G. ambigu$u m$ has priority.

\section{Specimens examined}

Tanzania. Western Prov.: Tabora Distr., Kipalapala, woodland, on soil, 1200 m, 12.XII.1991 Saarimäki \& al. 1073.

Geastrum hariotii (Lloyd) E. Fisch.

Myc. Notes: 311. 1907 — Figs. 5-6

Basidioma not hygroscopic, splitting into 6 equal pointed rays, $40 \mathrm{~mm}$ in diam, and $30 \mathrm{~mm}$ in height. Fleshy layer pale brownish. Fibrous layer whitish. Mycelial layer covered with debris. Endoperidium globose, $10-15 \mathrm{~mm}$ in diam, sessile, pale cream. Peristome sulcate, indistinctly delimited. Spores spherical, $3-4 \mu \mathrm{m}$ in diam, including ornamentation (Figs. 5-6) consisting of warts $0.3-0.5 \mu \mathrm{m}$ long. Capillitium solid, 2-5 $\mu \mathrm{m}$ diam, with abundant crystals on the surface, without branches.

Geastrum hariotii looks very similar to $G$. elegans Vittad., but that species has larger spores (5-6 $\mu \mathrm{m}$ in diam). G. hariotii has been found in Central Africa (Dissing \& Lange 1962) and reported from the Americas, Europe, Sri Lanka, East and West Indies and Australia (Dissing \& Lange 1962, Cunningham 1979).

Specimens examined

Tanzania. Tanga Prov.: Lushoto Distr., W Usambara Mts, Mazumbai Forest Reserve, on soil, $1500 \mathrm{~m}$, 9.XII.1989 T. Saarimäki 440.

Geastrum saccatum Fr.

Syst. Mycol. 3:16-17. 1829

We have examined only one basidioma, not very well preserved, but showing the same features as the European specimens (Sunhede 1989). We presume it is spread all over Africa (Bottomley 1948, Dring 1964).

Specimens examined

Tanzania. Southern Highlands Prov.: Iringa Distr., Sao Hill, Sawmills, on soil, 1900 m, 29.III.1991 Saarimäki \& al. 777 . 
Phallus impudicus L.: Pers.

Syn. Meth. Fung.: 242. 1801 - Fig. 7

The basidiomata show the typical features of this cosmopolitan species.

\section{Specimens examined}

Tanzania. Tanga Prov.: Lushoto Distr., W Usambara Mts, Mazumbai Forest Reserve, on rich soil, 1400 m, 19.IV.1991 Saarimüki \& al. 921.

Phallus tenuis (E. Fisch.) Kuntze

Rev. Gen. Pl. 2:865. 1891 - Fig. 8

Phallus amurensis (Jacz.) Pilát, in Fl. ČSR, Gast.: 710. 1958
Basidioma made up of a basal volva, pseudostipe and receptacle (Fig. 8). Volva conical, 8-12 × 4-8 mm, dirty white, covered with debris, carrying a rhizomorph. Pseudostipe cylindrical, attenuate towards the top, $25-33 \times 1-3$ $\mathrm{mm}$, spongy, yellowish orange when dry. Receptacle conical, $8-10 \times 2-5 \mathrm{~mm}$, reticulate, perforate on the top and partially covered with the olive brown gleba. Spores elliptical, $2-3 \times 1-1.5$ $\mu \mathrm{m}$, smooth, hyaline.

This is a very interesting species, apparently unknown in the Western hemisphere, but reported from China, Japan, Java and Sri Lanka (Liu 1984). Its tiny size, both of basidioma and spores, its yellowish pseudostipe and its habitat on rotten wood give it an almost unique taxo-

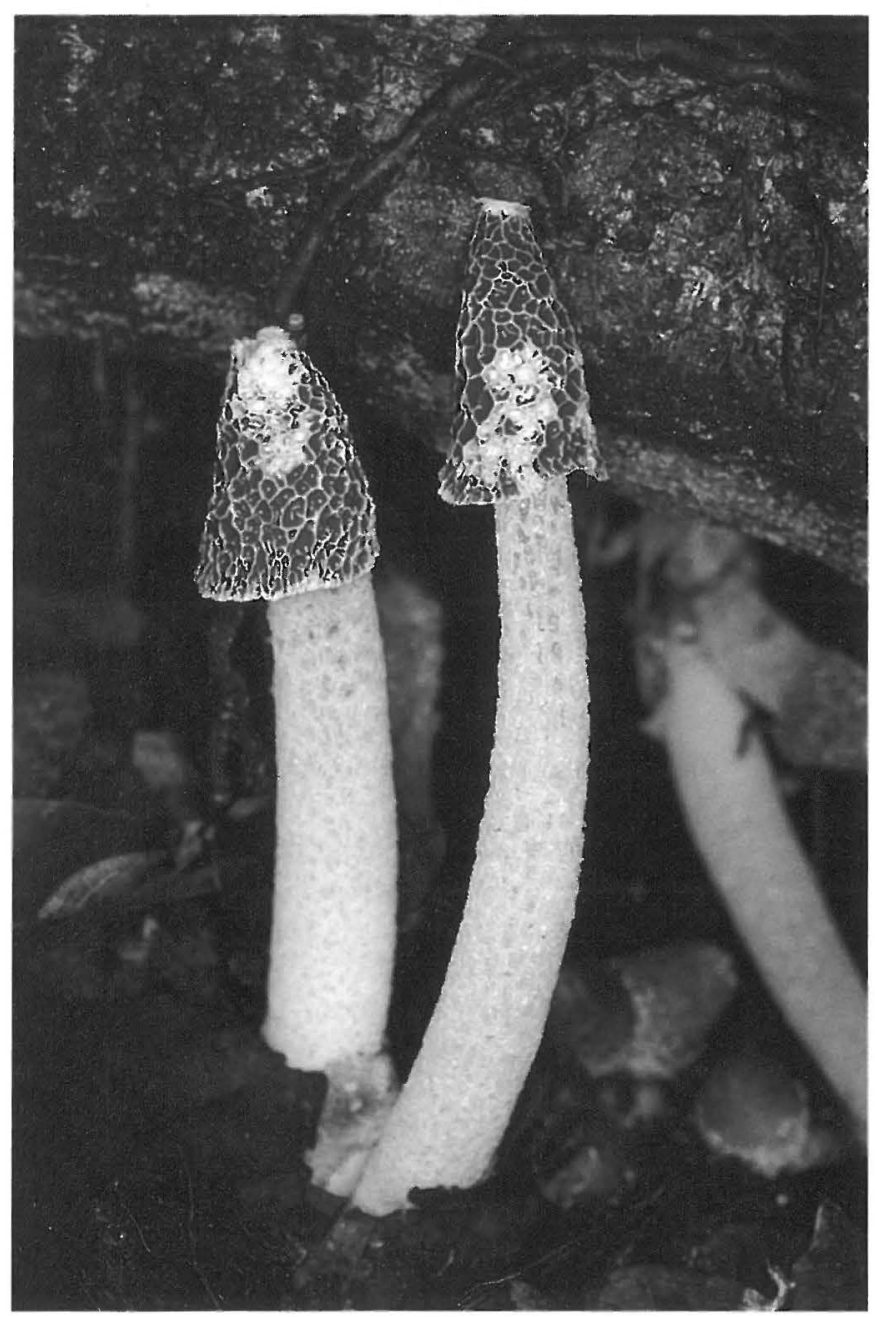

Fig. 7. Phallus impudicus. 


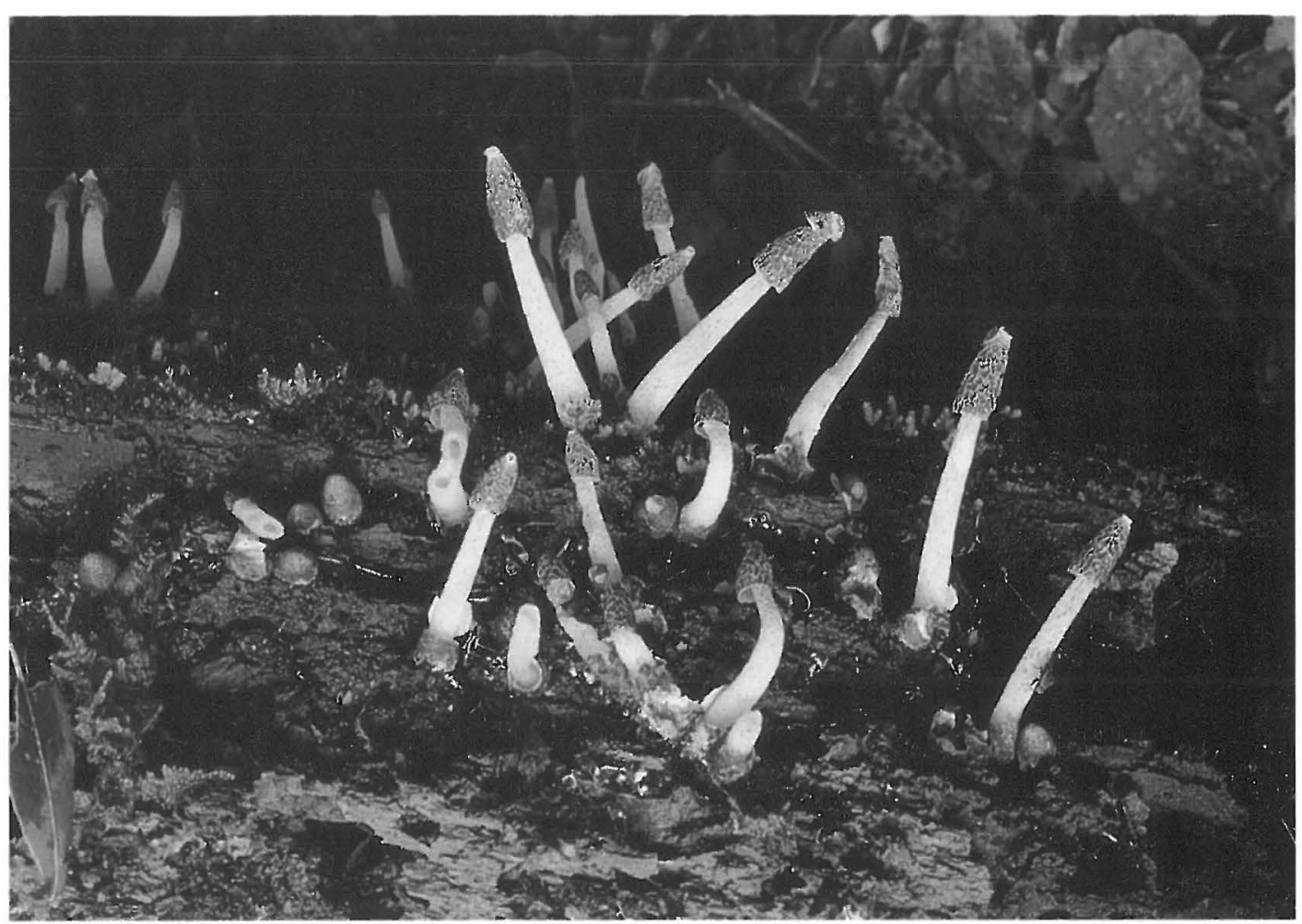

Fig. 8. Phallus tenuis.

nomical identity. However, it could be mistaken for $P$. costatus (Penz.) Lloyd, which also grows on decaying wood and shows some similar features, but with the following differences: pseudostipe pale yellow, 50-70 $\times 15-20 \mathrm{~mm}$, receptacle campanulate $25-40 \times 20-30 \mathrm{~mm}$ and spores $3.5-4 \times 1.5-2 \mu \mathrm{m}$ (Liu 1984).

\section{Specimens examined}

Tanzania. Tanga Prov.: Lushoto Distr., W Usambara Mts, Mazumbai Forest Reserve, on decaying wood, 1860 m, 8.XII.1989 Saarimäki \& al. 438.

\section{Scleroderma cepa Pers.}

Syn. Meth. Fung.: 155. 1801 - Fig. 9

This species is widespread in the world (Guzmán 1970), and easy to identify by its tough yellowish peridium, strongly echinulate, non-reticulate spores and the absence of a distinct pseudostipe (Calonge 1983).
Specimens examined

Tanzania. Southern Highlands Prov:: Rungwe Distr., Tukuyu, Ipondelo-Ikama village, under Cupressus sp., on soil., 1600 m, 27.III.1991 Saarimäki \& al. 739. Malawi. Zomba Distr., Makwawa village, $850 \mathrm{~m}$, 10.IV.1991 Saarimäki \& al. 813.

Scleroderma verrucosum Bull.: Pers.

Syn. Meth. Fung.: 154. 1801

This is also widespread in the world (Guzman 1970), close to Scleroderma areolatum Ehrenb., but with a longer pseudostipe and a dark brown peridium (Calonge 1983). S. areolatum is common in Sweden (Jeppson 1979) and Poland (Calonge \& Lawrynowicz 1986), but it seems to be replaced by $S$. verrucosum in the Mediterranean area (Calonge \& Demoulin 1975).

Specimens examined

Tanzania. Southern Highlands Prov.: Iringa Distr., Mufindi, Kibao, on soil, 1900 m, 20.III.1991 Saarimäki \& 


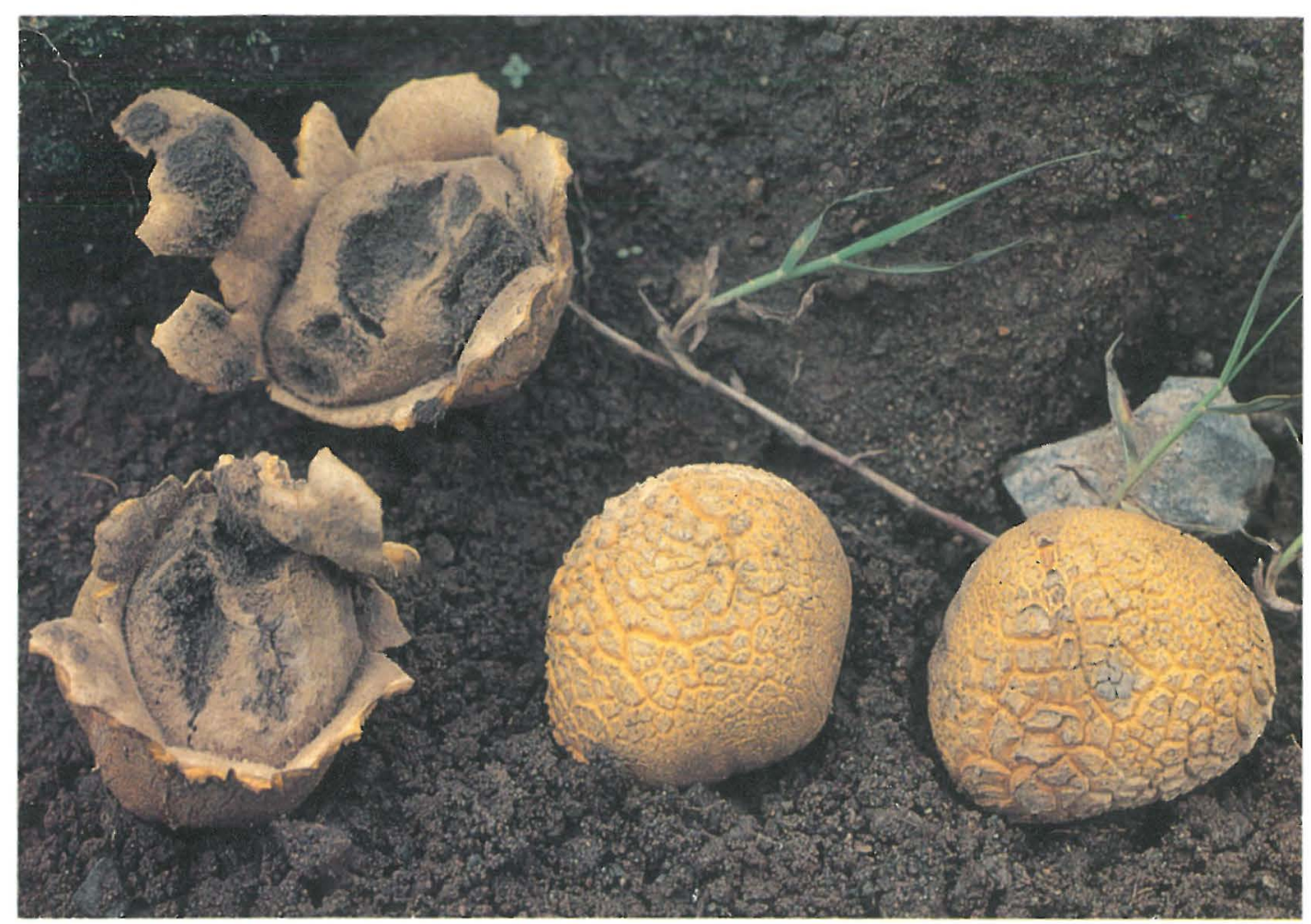

Fig. 9. Scleroderma cepa.

al. 676. Rungwe Distr., Tukuyu, Ipondelo-Ikama village, under Cupressus sp., 1600 m, 27.III.1991 Saarimäki \& al. 737.

\section{Dietary and other uses}

During our collecting trips in Tanzania, no tribe informed us that they use members of the class Gasteromycetes as food (Härkönen et al. 1995). Instead, in several places in Tanzania this group of fungi, especially puffballs, are used to sedate bees. The fungus is attached to a stick, set on fire and then pushed into a beehive. The smoke evidently stuns the bees and the hive can be emptied of the honeycombs.

Acknowledgements. Härkönen, Saarimäki and Mwasumbi, express their gratitude to the Finnish International Development Agency of the Ministry for Foreign Affairs (FINNIDA) and the University of Helsinki, and Calonge is grateful to the CSIC and DGICYT, project no. PB 92-0012, for funding of this work. Thanks are due to $M$. Jerez for his technical assistance with the scanning electron microscope.

\section{References}

Bottomley, A.M. 1948: Gasteromycetes of South Africa. - Bothalia 4:473-810.

Brodie, H.J. 1975: The bird's nest fungi. - 199 pp. Univ. Toronto Press, Toronto.

Calonge, F.D. 1983: El género Scleroderma Pers., (Gasteromycetes) en España. - Rev. Biologia 12:49_ 60.

Calonge, F.D. 1990: Check-list of the Spanish Gasteromycetes (Fungi, Basidiomycotina). - Crypt. Bot. 2:33-55.

Calonge, F.D. \& Demoulin, V. 1975: Les Gasteromycetes d'Espagne. - Bull. Soc. Mycol. France 91:247-292.

Calonge, F.D. \& Lawrynowicz, M. 1986: A contribution to the chorology of some Gasteromycetes in Poland. - Acta Mycol. 18:161-170.

Cunningham, G.H. 1979: The Gasteromycetes of Australia and New Zealand. - Bibliotheca Mycol. 67:1-236.

Dissing, H. \& Lange, M. 1962: Gasteromycetes of Congo. - Bull. Jard. Bot. Bruxelles 32:325-416.

Dring, D.M. 1964: Gasteromycetes of West Tropical Africa. - Mycol. Papers 98:1-60.

Eckblad, F.-E. 1976: Contributions to the gasteromycetflora of Iran. - Iranian J. Bot. 1:65-69. 
Guzmán, G. 1970: Monografía del género Scleroderma Pers. em. Fr. (Fungi, Basidiomycetes). - Darwiniana 16:233-407.

Härkönen, M. 1992: Wild mushrooms, a delicacy in Tanzania. - Univ. Helsingiensis 12:29-31.

Härkönen, M., Buyck, B., Saarimäki, T. \& Mwasumbi, L. 1993a: Tanzanian mushrooms and their uses 1. Russula. - Karstenia 33:11-50.

Härkönen, M., Saarimäki, T. \& Mwasumbi, L. 1993b: Tanzanian mushrooms and their uses 2. An edible species of Coprinus section Lanatuli. - Karstenia 33:51-59.

Härkönen, M., Saarimäki, T., Mwasumbi, L. \& Niemelä, T. 1993c: Collection of the Tanzanian mushrooms heritage as a form of developmental cooperation between the Universities of Helsinki and Dar es Salaam. - Aquilo Ser. Bot. 31:99-105.

Härkönen, M., Saarimäki, T. \& Mwasumbi, L. 1994a: Setting up a research project on Tanzanian mushrooms and their uses. In: Seyani, J.H. \& Chikuni, A.C. (eds.), Proceedings of the 13th Plenary Meeting of AETFAT Zomba, Malawi, 2-11 April 1991, 1:729-734. Nat. Herbarium \& Botanic Gardens of Malawi, Zomba.

Härkönen, M., Saarimäki, T. \& Mwasumbi, L. 1994b: Tanzanian mushrooms and their uses 4. Some reddish edible and poisonous Amanita species. Karstenia 34:47-60.

Härkönen, M., Saarimäki, T. \& Mwasumbi, L. 1995: Edible mushrooms of Tanzania. - Karstenia 35 suppl.:1-92.
Jeppson, M. 1979: Notes on the occurrence of Scleroderma areolatum and Scleroderma verrucosum in Sweden. - Göteborgs Svampklubbs Årsskrift 1979:39-44.

Kreisel, H. 1975: Gasteromyceten aus der Mongolischen Volksrepublik. - Feddes Rep. 86:321-327.

Kreisel, H. 1976: Gasteromyceten aus Nepal II. - Feddes Rep. 87:83-107.

Liu, B. 1984: The Gasteromycetes of China. - Beih. Nova Hedwigia 76:1-235.

Saarimäki, T., Härkönen, M. \& Mwasumbi, L. 1994: Tanzanian mushrooms and their uses 3. Termitomyces singidensis, sp. nov. - Karstenia 34:13-20.

Saccardo, P.A. 1888: Gasteromyceteae. - Sylloge Fungorum 7:34.

Staněk, V. I. 1958: Geastrum. In: Pilát, A. (ed.), Flora ČSR B-1. Gasteromycetes: 494, 792. - Praha.

Sunhede, S. 1989: Geastraceae (Basidiomycotina). Morphology, ecology, and systematics with special emphasis on the North European species. Synopsis Fungorum 1:1-534.

Wolf, F.A. 1949: Notes on Venezuelan fungi. - Lloydia 12:208-219.

Received on 11 December 1995 